\title{
Splint for Compound Fractures
}

\section{S. Stacy Skipton M.D.}

To cite this article: S. Stacy Skipton M.D. (1862) Splint for Compound Fractures, Royal United Services Institution. Journal, 6:24, 453-455, DOI: 10.1080/03071846209418202

To link to this article: http://dx.doi.org/10.1080/03071846209418202

\section{曲 Published online: 11 Sep 2009.}

Submit your article to this journal $\pi$

Џ Article views: 2

Q View related articles $₫$ 


\title{
SPLINT FOR COMPOUND FRACTURES.*
}

\author{
Bj S. Stacy Snirtox, M.D., Assistant Surgeon, 78th Highlanders.
}

I AM anxious to bring to the notice of the Members of the Royal United Service Institution, by means of this paper, a design of an apparatus or splint for "compound" fractures of the limbs; i.e., those fractures accompanied with a wound which exposes the fractured bone to the air, such as are caused by gunshot, or other missiles of war.

In the surgical treatment of these injuries, in themselves always serious to the safety of the limb, if not actually dangerous to life, the great object is to apply a splint to support the broken bones in their proper position, at the same time that the wound or rounds in the linb may be left exposed for the applicntion of the requisite dressings.

In the military serrice, and especially with an army in the field, if cannot be expected that the officers of the medical department can lave access to the same resources that are arailable to the surgeons of a civil hospital, who are surrounded by all the materials which a liberal manngement permit them to make use of, modify and eut up, if need be, in order to meet the requirements of any one particular case under their care, and so render these materials useless for future casualties unless they present precisely the same conditions as the former one. With medical officers in the Army, on the contrary, economy in the amount of supplies of surgical apparatus is a primary consideration, and especially so under those circumstances in which they are likely to be most required, with an army in the field in the presence of the enems; and with $u s$, of course taking into consideration that this "field" is in a foreign country, and, niay be, at a long distance from our base of supplies.

In the hospitals at Scutari and in the Crimea, in 1854-55, when the wounded arrived from the battle-fields of the Alma, Balaklara, and Inkermann, and from the trenches before Sebastopol, it mas distressing to see them lying with fractures of the limbs from gun-shot injuries, for which no apparatus could be extemporised to meet the requirements of the vast majority of these cases. The medical officers were therefore compelled to use the ordinary splints from the stores, and, unfortunately, from the site of the wound being in the course of the splint, and requiring washing and dressing erery day, the poor sufferer, officer or private, was daily put to the serere pain consequent upon the splint being remored, the wound cleansed and dressed, without any allequate support to the injured limb, and then the splint itself, which slould have rendered this needful support to the broken bones, re-applied. Only those who have themselves suffered from a broken limb, and lnow what is the pain of having "the bones set," can form an idea of the suffering entailed upon our wounded; and, when we consider the constant state of ferer which was maintained by this frequent but unaroidable meddling with the broken bone, it is not to be wondered at that so mans of these severe injuries terminated unfarourably, necessitating, at the lenst, the sacrifice of the limb.

As, then, the requirements of the military service deny to a surgeon in

yoL. VI.

- Communicated 21st June, 1862.-E. 
the field the great advantages possessed by a civilian surgeon, and render it necessary for the former to regard, while consistent with their complete efficiency, the porvbility, simplicity, and durability of his surgical apparatus, with ceonomy also in the numbers and sizes of the splints he carries in his hospital stores, an apparatus or splint so designed as to meet all these requirenents struck me as being, not only desirable, but exceedingly necessary; and such, I trust, will that be found a description of which $I$ have now the gratifiention of submitting. The shape of the splints for the rarious limbs remains the same as those in common nse, and the material best fitted for rough usage on a campaign, and which is by far the most cleanly of all, is the thin shect-iron lacquered over, such as the ordinary splints have heretofore been male of. MYy object being to provide a splint, the surface of which might be capable of being interrupted at any part of its length, where, when applied to the limb, it might cover the site of a round, I have taken any one of the common splints, cut it across into transverse strips, ench of a width sufficient when remored to uncorer a space the size of a gunshot wound, and at the back of these transverse strips placed vertical plates haring holes pierced therein for a longitudinal bar, running along the back of the splint, to pass through : the terminal pieces of the splint are fixed to these longitudinal bars by rivets or screws at either end.

The accompanying dratrings of the rarious splints, depicting a sideplan riew of a splint for the arm and fore-arm, leg and thigh, respectively; show each to be composed of transrerse strips (see Plate, $a, a$,) which, placed side by side, form the shape of tho required splint; upon ench of these are placed rertical plates $b, b$, (shown in a front vier at the sections at $A, A$, B, B, C, C, which hare a hole pierced therein for a longitudinal bar, $d, d$, to pass through : each terminal piece of the splint is supplied with pillars $e, e$, and set serews $f, f$, or rirets to keep these pieces in their respective positions and required distances on the bars. Each transrerse strip being numbered consecutively, no mistake need occur by their becoming misplacel, and thereby disarranging the shape of the splint. By loosening the screms and withdrawing the terminal piece from the bars, any one or more of the transrerse pieces corering the site of a wound may be remored and set aside, and the terminal piece and the others replaced in their former position. The splint thus applied, and bound on the limb with straps passing under the bars, presents an interruption in its surface, and, by leaving the wound uncovered, gires facility for cleansing and dressing it, withont disturbing the support of the splint on the limb. The distance betreen the bars and the surface of the splint, or rather of tho limb to which it is applied, renders any manipulation to the round practicable and easy, and at the same time the patient is saved the agony and suffering, and consequent irritative ferer, caused by having to remore and re-apply the splint to the broken limb after dressing the wound. Another adrantage attendant upon this apparatus is, that the "pads" or cushions between the splint and the limb, and the bandages or straps which secure it to the limb, are more easily retained in a cleanly state; a desideratum to be appreciated chiefly by those who have serred and suffered these injuries in a hot climate, such as that in which our campaigns have hitherto been carried on. 


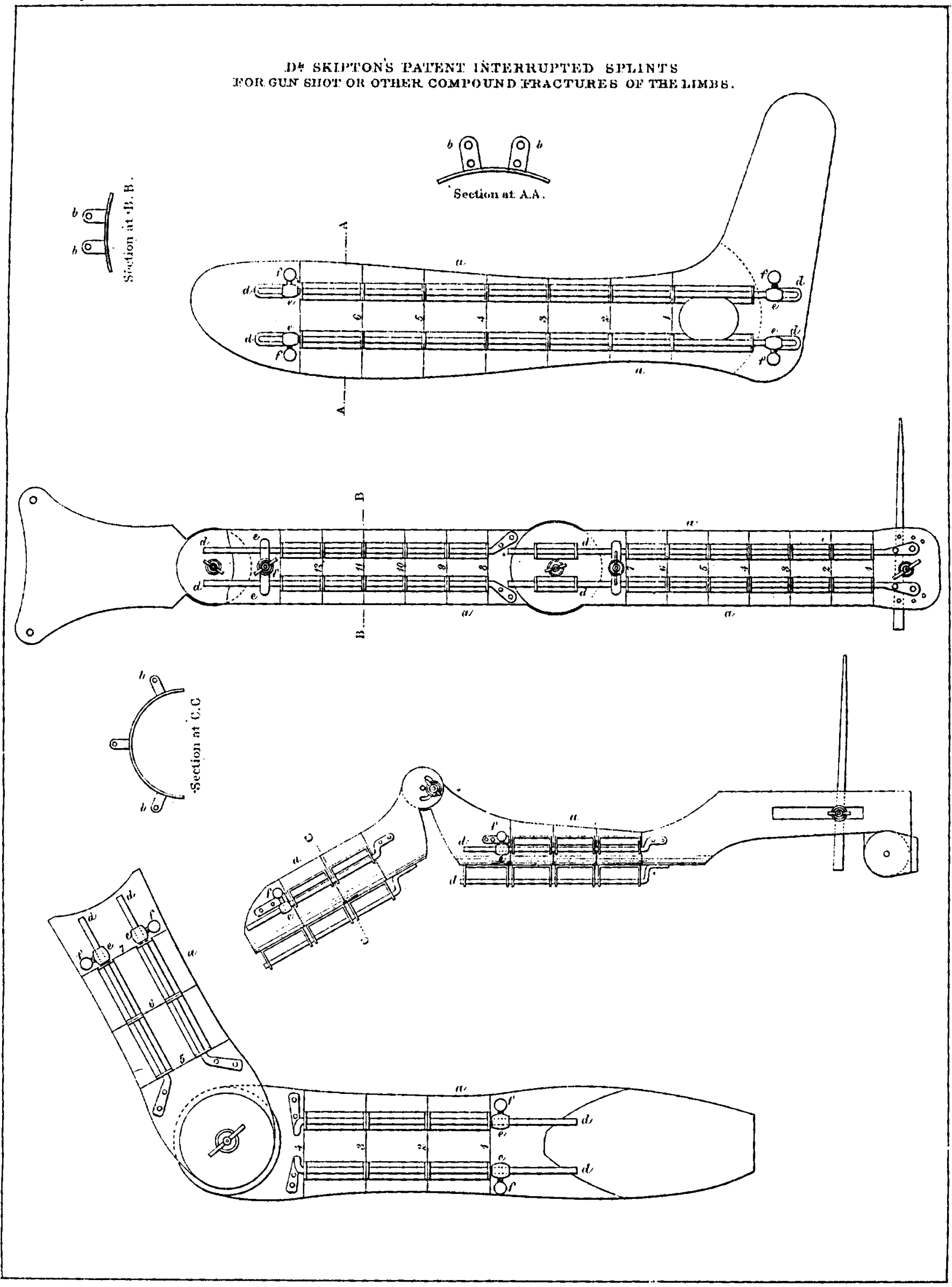


I hare described the principal adrantages which this apparatus possesses abore the common splint heretofore in use; but there is one other yet to he mentioned, and which, with the above, it exclusirely presents; and one especially to be appreciated by our medical officers, whose resources as regrards the numbers of the rarious sizes of splints must be considerably limited, whether at home or abrond. This consists in the same splint, which, at the full length of the longitudinal bars, rould be sufficiently longt for a tall man, being capable of reduction in length by remoring one or more of the transverse strips, and bringing down the terminal pieces along the bars, and so making the splint short enough for a drunmer-boy; thus relieving another great necessity of the service, economy in the numbers of the splints supplied to 5 force, and ensuring more comfort to the patient than he would have experienced from such apparatus as tre had for use at Scutari in 1854, and later, during the Indian Mutiny, where, in many instances, orring to the enormous number of wounded suddenly taken under treatment, the splints were, in addition to their great disadrantages above referred to, either too short or too long for some particular case.

While the abore would appear to be sufficient to recommend its adoption in those instances in which there is a wound co-existent with the fracture, this splint may also be used in cases in which there is no wound, in which the fracture is styled "simple." In these, the transrerso strips would be left on the bars, no interruption of the surface of the splint being required; and the only objection to be raised against them-viz., their slight extra weight, which the additional quantity of the material in the bars, \&c., renders unaroidable-is discarded as immaterial, when we consider that the patient is lying in bed, and required to keep his limb perfectly still, especially if the fracture be "compound." If the arm or fore-arm be the limb affected, and the patient be so far conralescent as to be allowed to be up, this extra weight is.then supported in a sling from the neck.

Hitherto I have only spoken of this "Interrupted" splint as being adrantageous to military medical officers, but the same reasons that would promote its adoption in the army medical department, where it has already established itself, would also render it requisite in civil life, to surgeons in charge of the rarions unions, and to those in country practice, who are bound to as strict an economical use of the materials and appliances at their command as possible, and who will not fail to see that the expense of these splints once incurred, will relieve them of the annorance and trouble attending "make-shift" appliances, and always render them capable of nttending at once and satisfactorily to any case of the serious nature above referred to, which may come suddenly under their care.

As medical officers form but a small minority of the members of the Royal United Service Institution, in writing the above, I hare enlarged more freely on the strictly professional branch of the subject than I rould otherwise have done; but I trust I may be excused for this, and hope that the public importance of the subject may be considered as a sufficient warrant.

\footnotetext{
* I should mention in conclusion, that the manufacturers of this apparatus are Messrs. Whicker and Blaise (late Savigny \& Co.), No. 67, St. James's Street, Pall Mall, S.W., who supply the army medical department with surgical instruments._S.S.S,
} 